\title{
CFD study to improve PV cell performance by forced air: Modern design
}

\author{
Ahmed Mohsin Alsayah ${ }^{1}$, Mahdi Hatf Kadhum Aboaltabooq ${ }^{2}$, Mahir H. Majeed ${ }^{3}$, Bassam Abed Saheb \\ M. Hussein ${ }^{4}$ \\ ${ }^{1,2,3,4} \mathrm{Al}$-Furat Al-Awsat Technical University
}

\section{Article Info}

Received, 2019

\section{Keyword:}

Photovoltaic efficiency,

Air guide model, solar energy

Air cooling

\begin{abstract}
A theoretical study was conducted on the performance of photovoltaic cells by forced airflow on the cell base. The study was conducted using numerical simulation software (ANSYS- cfx) to select the best model for its manufacture. The simulation results showed that the air guides model is the best, directing the largest amount of air to the base of the cell and the lowest cost and available in local markets. Air guides shall be installed inside an aluminum channel fixed to the bottom of the cell base and the channel dimensions shall be selected according to the dimensions of the photovoltaic cell to be cooled. A numerical study determine the best number and best location of the air guides inside the duct channel and the tilt angle of air guides and showed that the optimum number of pneumatic guides is $(18)$ in a position $(70 \mathrm{~mm})$ from the base of the channel and at a 45-mile angle with the horizon.
\end{abstract}

\section{Corresponding Author:}

First Author,

Engineering Technical College-Najaf, Iraq

Al-Furat Al-Awsat Technical University,

Iraq-najaf-kufa

Email: ahmad.m.alsaiah@gmail.com

\section{Introduction}

The various renewable energy applications need mainly solar incident radiation with a total value of 3.8 million watts per year, and hybrid photovoltaic (PV / T) systems are better than other applications because they produce electricity and thermal simultaneously [1].The photovoltaic cell is characterized by receiving direct solar radiation[2], converting part of it to direct electrical energy and the other part to thermal energy. The photovoltaic system can produce both thermal and solar energy simultaneously[3]. There are several types of these solar systems that can be used in many different applications and engineering fields [4]. PV / T systems characterized by simultaneous production of thermal and electric energy can be classified into two main categories depending on the fluid used to collect and absorb thermal energy. Air or fluid is usually used as a fluid to cool the PV cell and absorb the heat produced from the PV cell. There is a variety of cooling and collecting methods generated by photovoltaic cells, which typically contribute to increasing the electrical efficiency and performance of pv cell [5]. In addition to the primary function of photovoltaic cells, which is the production of electric power, dispensing with fossil fuels and contributing to the improvement of the environment, the thermal energy derived from the cooling process of pv cell can be utilized in several different fields including drying, geothermal heating and desalination using solar energy technologies[6] . 
However, the specialists in the field of investment of thermal energy produced by photovoltaic cells faced a number of obstacles and shortcomings in the thermal efficiency of pv cell. Thermal efficiency is often low relative to the solar radiation on the photovoltaic cell[7]. In addition to the significant decrease in the electrical energy of the cell [8] A study by researchers Ekechukwu and Norton showed that the maximum thermal tingling of a typical PV system ranges from $40 \%$ to $50 \%$. As for PV / T, which uses air as a cooling fluid, its average thermal efficiency ranges from $10 \%$ to $20 \%$ [9] . Wijeysundera et al.[10] Also conducted a similar study on the thermal performance and thermal efficiency of air heaters that use solar energy with double glazing as well as multi-glass and single-glass[11].

The results of previous studies of researchers on the maximum thermal efficiency of the hybrid system that produces thermal energy and electrical energy together PV / T where a study used two types of photovoltaic cells type glass to plastic and type glass to glass The results of the study showed that the performance of the hybrid PV cell system from glass to glass Better performance by producing thermal energy than other type glass to plastic[12]. There were many techniques of cooling the photovoltaic cells, which researchers were interested in detailing their methods and the benefits and harms of each method[13][14]. The difference between a photovoltaic (hybrid) system and a photovoltaic system is that the first produces electrical energy and heat together and the second produces only electrical energy. Solar energy, which is not converted to electrical energy, represents thermal energy that undesirably affects the electrical performance and efficiency of the photovoltaic cell. In this study, a modern model was tested through by CFD simulation program to reach the highest heat exchange between the air used as a cooling fluid and the PV base.

\section{Analysis of cooling system by air guides}

The photovoltaic cooling system is illustrated by the air guides addressed and discussed in this paper. The design of the air guides solves the problem of the rise in cell temperature photovoltaic and improves its performance. the photovoltaic cooling system that is supposed to be designed to improve the performance and efficiency of the photovoltaic cell. Air guides were first time used and will be designed with numerical simulation software. The geometry of the air guides was drawn by Solid Works program before being used by CFD program. The characteristics of the photovoltaic cell cooling system are simulated and the optimal design is chosen, which gives optimum results by using CFD PRGRAM Software simulation program to reduce the temperature of the PV cell base for the purpose of increasing the efficiency and performance of the cell. The length and width of the channel were chosen along the length and width of the cell (1956* 992) millimeters [15]. The channel height from a previous study that examined the effect of channel height to channel length on cell efficiency. The best height is $100 \mathrm{~mm}$. Using a dynamic digital program (CFD), dynamic properties such as air conduction heat transfer coefficient and heat transfer coefficient of coolant flowing towards the photocell base were achieved to reduce the cell temperature.

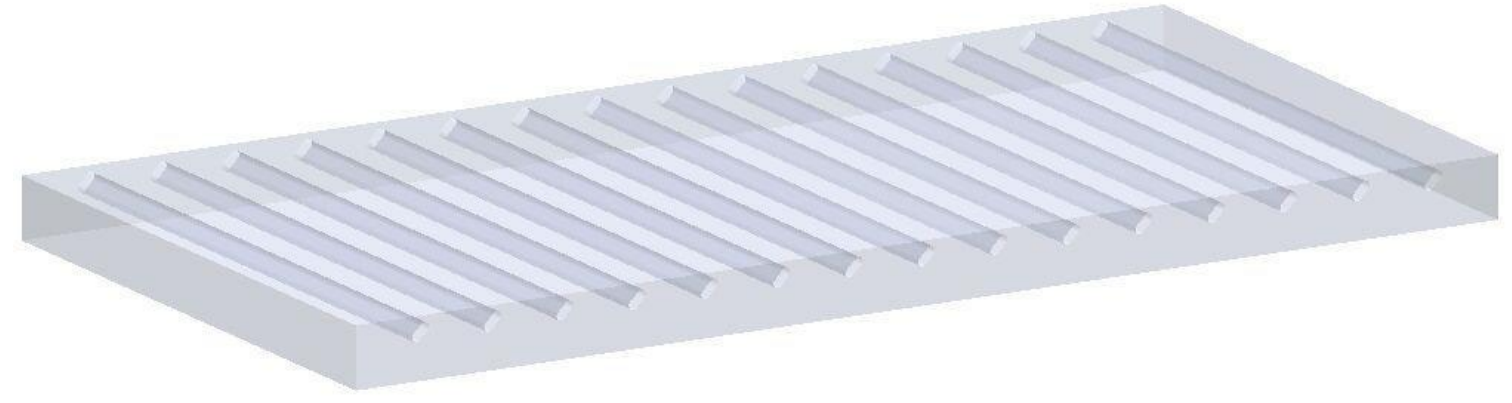

Fig.1. Illustration of air guides by the SOLD WORK program

For the purpose of simplifying the solution and reaching the most results with the realities, the following hypotheses were imposed:

1- The air is uncompressed liquid

2- Air duct fully insulated from outside 
2- Solar radiation is constant

4- The temperature of the incoming air is equal to the ambient air temperature

The governing mathematical equations used to express the heat transfer between the air and the PV base are differential equations and describe the flow of air towards the base of the cell[16][17]. They are used and represented as follows:

Conservation of mass (continuity)

$$
\nabla(p D)=0
$$

Conservation of momentum

$$
\rho \frac{D V}{D t}=-\nabla P+\rho g
$$

\section{Conservation energy for fluid}

$$
\mathrm{V} \cdot \nabla\left(\rho \mathrm{CP}_{\mathrm{p}} \mathrm{T}_{\mathrm{f}}\right)=\nabla \cdot\left(\mathrm{K}_{\mathrm{f}} \cdot \nabla \mathrm{Tf}\right)
$$

\section{Conservation of energy for solid}

$$
\nabla .\left(\mathrm{K}_{\mathrm{w}} \quad . \nabla \mathrm{Tw}\right)=0
$$

Using the CFD PRGRAM engineering simulation program, the thermal analysis of the air duct and the air guides installed inside the duct have been completed and will be connected to the base of the PV cell. It was taken into account that the model (k-Omega) and airflow would be turbulent flow (Re> 2200). Using the firstorder upwind scheme, continuity equations, airflow momentum and energy equations were solved. The simulation system consists of 30137 elements as well as 29226 nodes. The boundary conditions implemented on the model are the same as the standard operating conditions of the PV panel where the air flowing through the air duct receives a constant thermal intensity from the heat falling on the PV cell. The incoming air temperature is supposed to be 25 degrees Celsius. Since the intensity of the solar radiation falling on the PV cell and the ambient temperature depend on time during daylight hours. Therefore, the temperature of the cell is imposed and is dependent on the ambient temperature. Depending on the standard conditions, the initial temperature of air was 25 degrees Celsius for the air entering the air duct. A variable air fan speed was started from from $1 \mathrm{~m} / \mathrm{s}$.

\section{Results}

In this section, we present all the results achieved in the design of the channel and air guides and their effect on the PV cooling system. The temperature of the outgoing air will be an important criterion for the heat exchange between the air flowing towards the base of the cell and the base of the cell. Where the temperature of the outside air increases as more heat is gained from the base of the cell and therefore the temperature of the base of the cell decreases.

The simulation results for the design of the proposed duct channel are presented in Fig. (1, 2, 3 and 4 to 12) The standard selection of the best model is the outlet air temperature, which gained heat from the base of the cell after heat exchange.. A model of air guides was selected at distances available in local markets and economic costs were reduced. For the purpose of finding the best design for the air evidence model, the following steps and tests were adopted:

1. Select the best number of air guides inside the duct. 
2. Location of air guides (distance from the base of the cell)

3 .Test the tilt angle of air guides

4. Number of air guides within the channel (one or two rows)

5. Test irregular distribution of air guides

The results of the test by using the CFD PRGRAM simulation program showed that the best number of air encounters is 18 air guides in one row within the air channel at a 45 degree tilt angle $30 \mathrm{~mm}$ from the cell base is the best model compared to other models. The simulation model depends on the amount of solar radiation and ambient air temperature. The speed of the surrounding air, the air characteristics and the velocity of air entering the channel are the most important factors in the analysis.

\subsection{A simulation Results of the two-row model and irregular distribution}

The double-row test of air guides gave a low temperature compared to the one row where the temperature of the air outlet out of the heat exchange process was $301.5^{\circ} \mathrm{C}$ and the reason is that the double row of air guides represents a blockage of air movement, which reduces the heat exchange process.

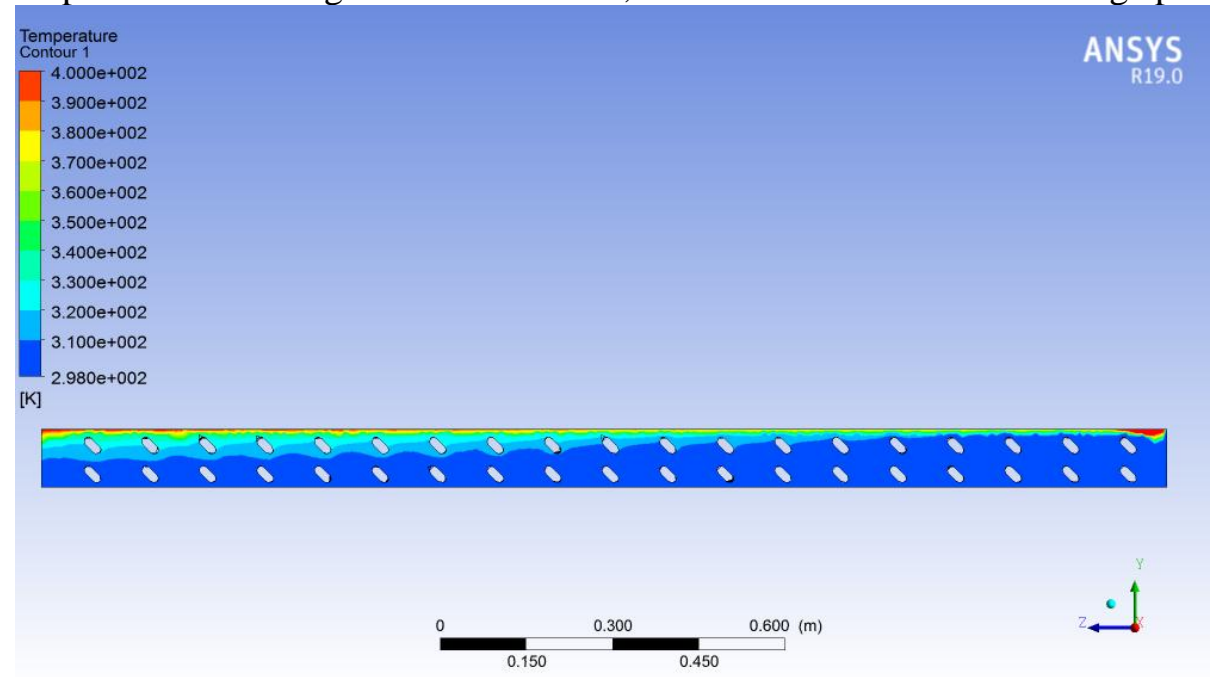

Fig. 2. The outlet air temperature for two rows of air guides by regular distribution

The distribution of air guides Zkzak that the locations of heat exchange irregularly distributed and increased at the point where the one air guide and low site where a dual antenna guide and the reason is the obstruction of the airway, which led to increased pressure drop, which represents losses in addition to the system and the outlet air temperature after the exchange process is $317.14{ }^{\circ} \mathrm{C}$.

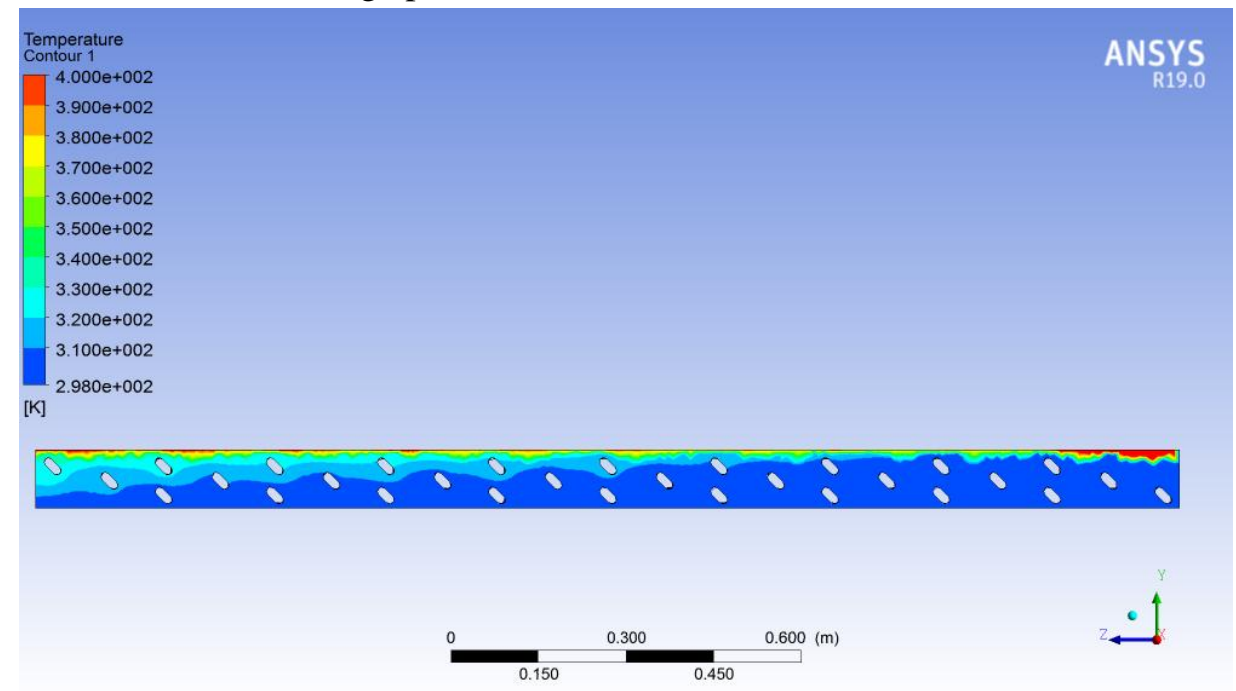

Fig. 3.The temperature of the air outlet the two rows of air guides through irregular distribution 


\subsection{Test the optimal number of air guides within the air duct}

Choosing the right number of air guides is essential to achieve the goal of using air guides. It directs the largest amount of air towards the base of the PV cell and increases the heat exchange between the base of the cell and the air. Selecting the appropriate number reduces the cost of using unnecessary numbers. by experimenting with multiple models Of the air guides by using the ANSYS-CFX program and the following results are shown in the fig. $(3,4,5,6)$.

Table 1. Number of air guides result

\begin{tabular}{|l|l|l|}
\hline Case & Number of air guides used & outlet air temperature (K) \\
\hline one & 15 & 340.291 \\
\hline two & 16 & 342.05 \\
\hline three & 17 & 343.01 \\
\hline four & 18 & 345.31 \\
\hline Five & 19 & 343.08 \\
\hline
\end{tabular}

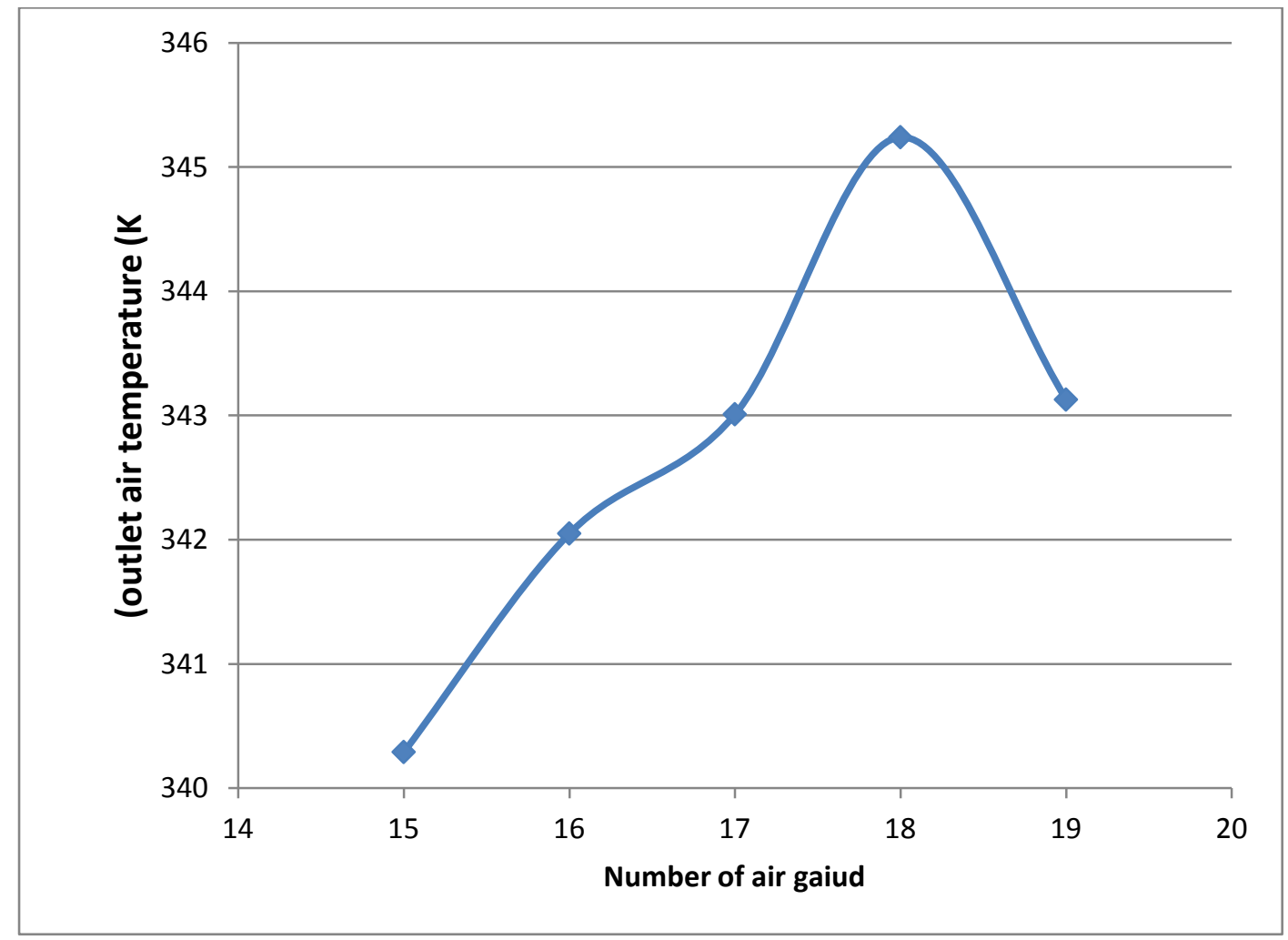

Fig. 4. Choosing the best number of air guides by CFD PRGRAM 


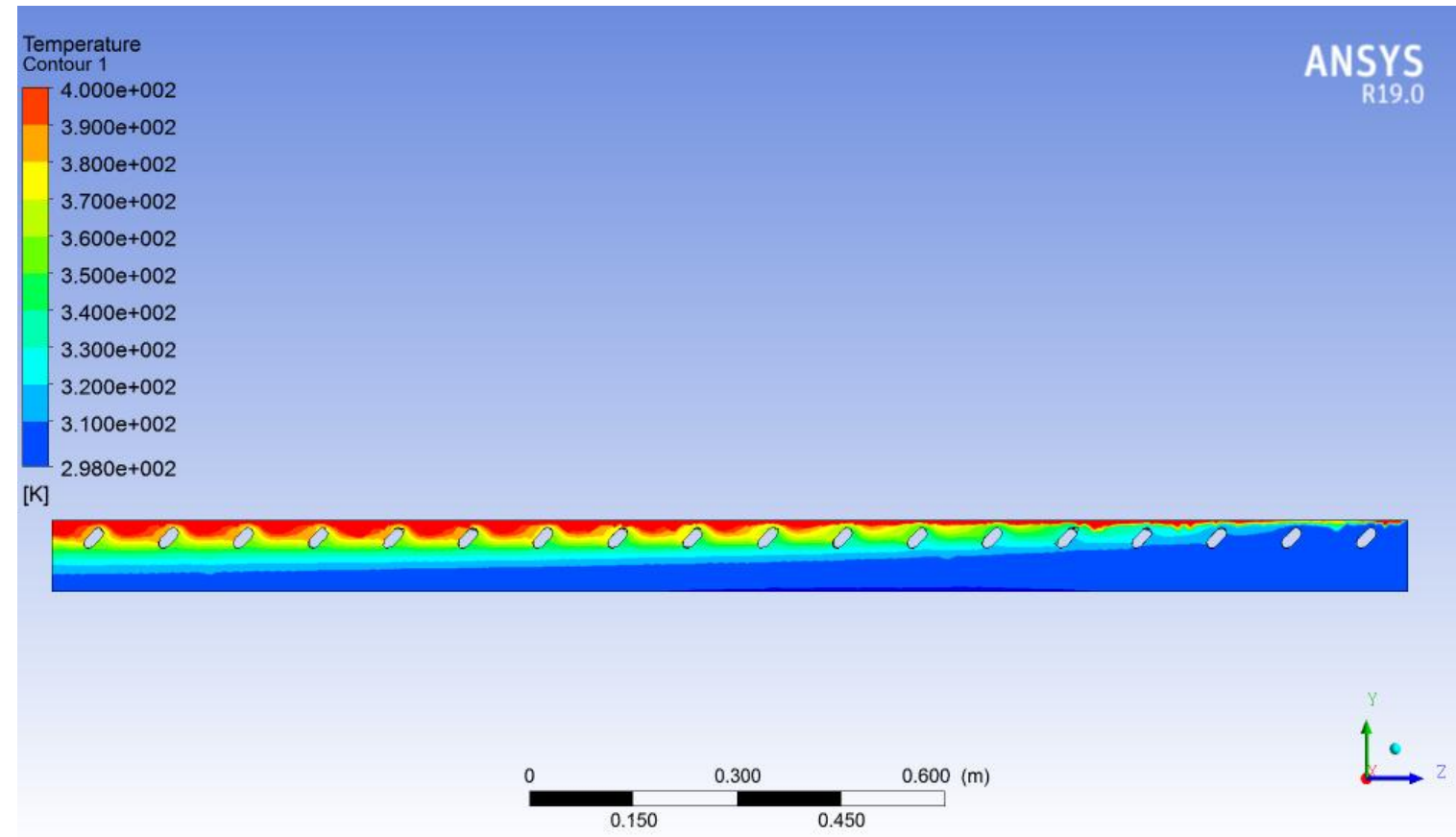

Fig. 5. Optimum number of air guide is 18 and the outlet air temperature is $345.24 \mathrm{~K}$ by ANSYS-CFX air guides location at a distance of $70 \mathrm{~mm}$ from the base of the cell where the outlet air temperature was 317.02 Kelvin, which was lower than when the air guides were located $30 \mathrm{~mm}$ from the base of the cell, where the outlet air temperature reached 345.24 Kelvin as shown in Fig.5.

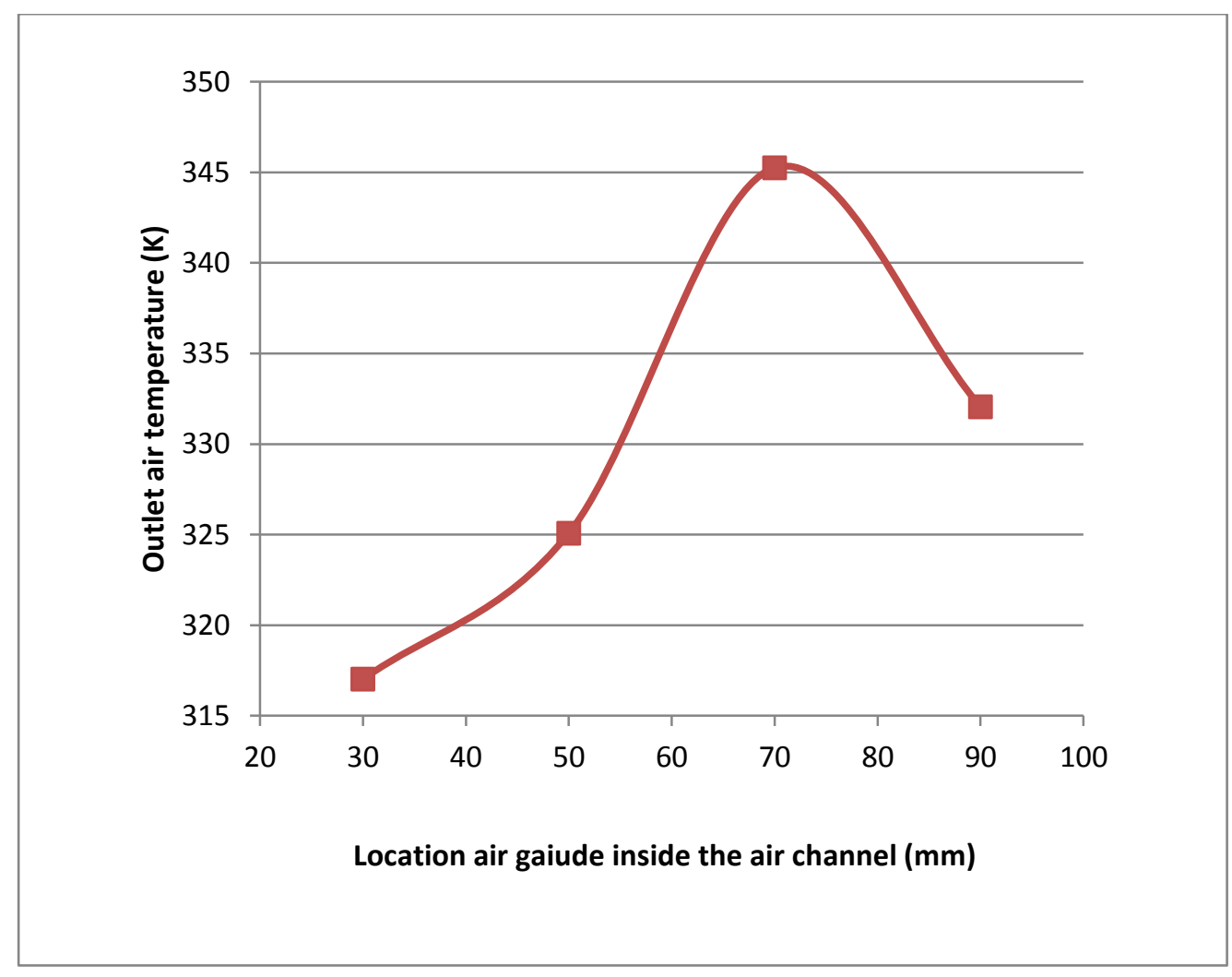

Fig. 6. Location air gaiude inside the air channel test. 


\subsection{Effect of airflow rate on outlet air temperature}

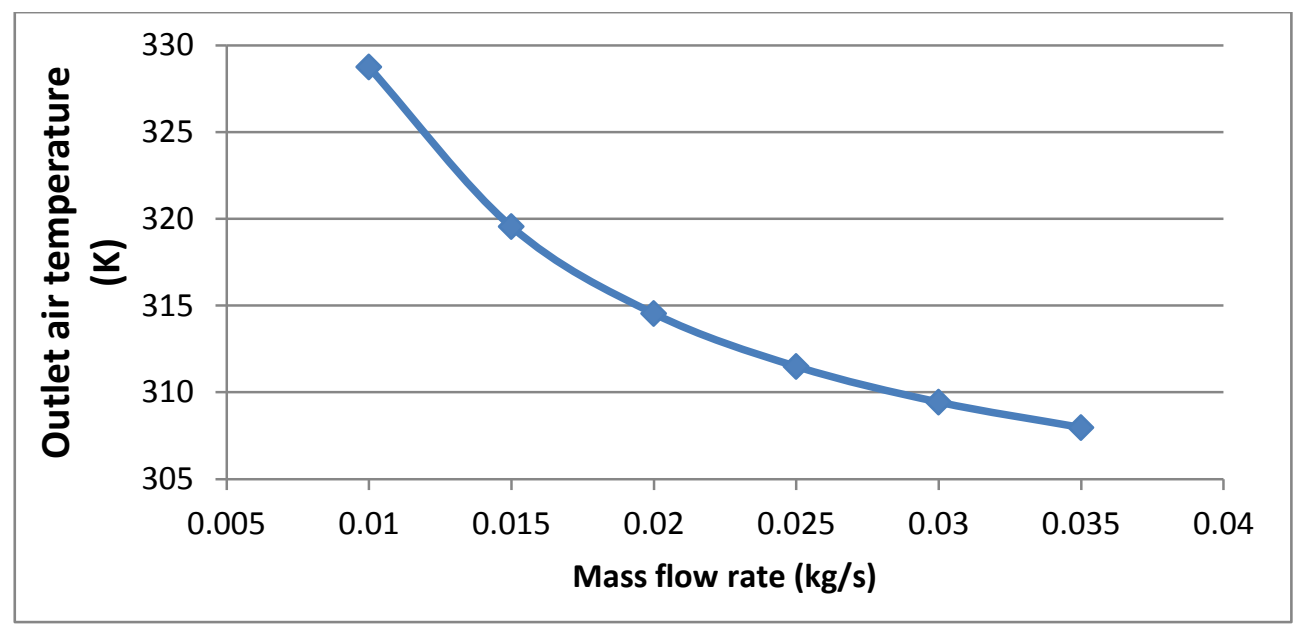

Fig. 7. Optimal flow rate test which gives a best temperature for outlet air

From fig. 6. , the outlet air temperature is significantly reduced with increasing fan speed and thus means that the air flow rate is inversely proportional to the outlet air temperature. The heat exchange between the air and the base of the photovoltaic cell decreases when the speed is high, as the air cannot get a large amount of heat by staying in contact at very short time with the base of the photovoltaic cell. The cooling fluid (air) needs to flow slowly under the base of the cell to gain heat energy from the base of the cell and put it out. It is useful to mention that low air speed means low power consumption required by the air intake fan which means increasing the electrical power produced from the cell after the cooling process. In the ANSYS test, a set of mass flow values for air flow were selected at the same test : (Solar radiation intensity $1000 \mathrm{watts} / \mathrm{m}^{2}$, inlet air temperature $25^{\circ} \mathrm{C}$.

Table 2. Air mass flow rate result

\begin{tabular}{|l|l|l|}
\hline Case of air mass flow & Mass flow rate $(\mathrm{kg} / \mathrm{s})$ & Air outlet temperature $(\mathrm{K})$ \\
\hline 1 & 0.01 & 328.76 \\
\hline 2 & 0.015 & 319.56 \\
\hline 2 & 0.02 & 314.547 \\
\hline 3 & 0.025 & 311.494 \\
\hline 4 & 0.03 & 309.438 \\
\hline 5 & 0.035 & 307.971 \\
\hline
\end{tabular}

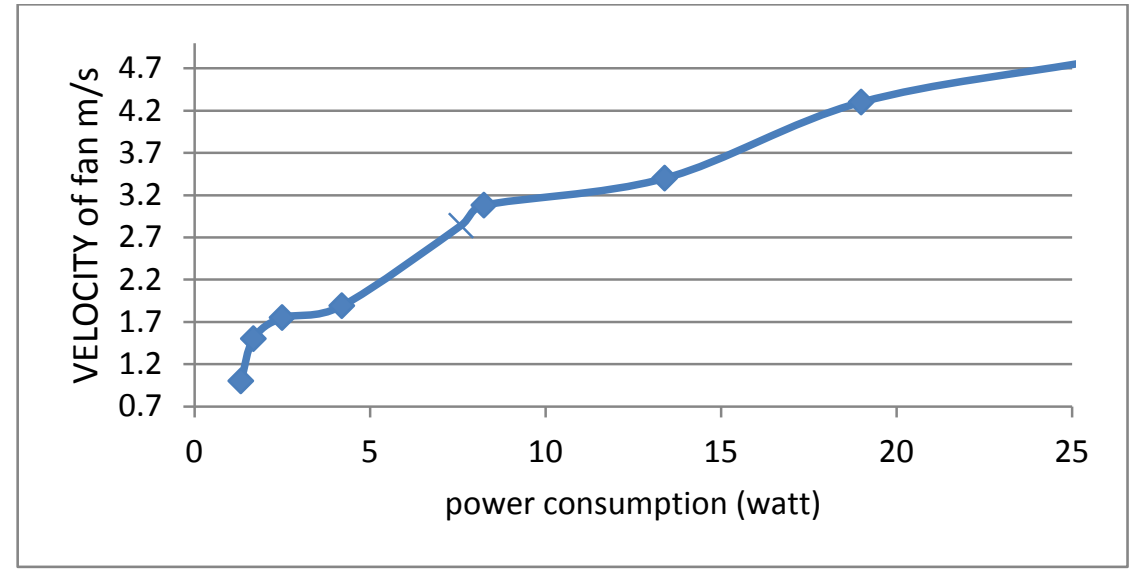

Fig. 8. The average power consumption of the air pull fan used in the system at each speed 


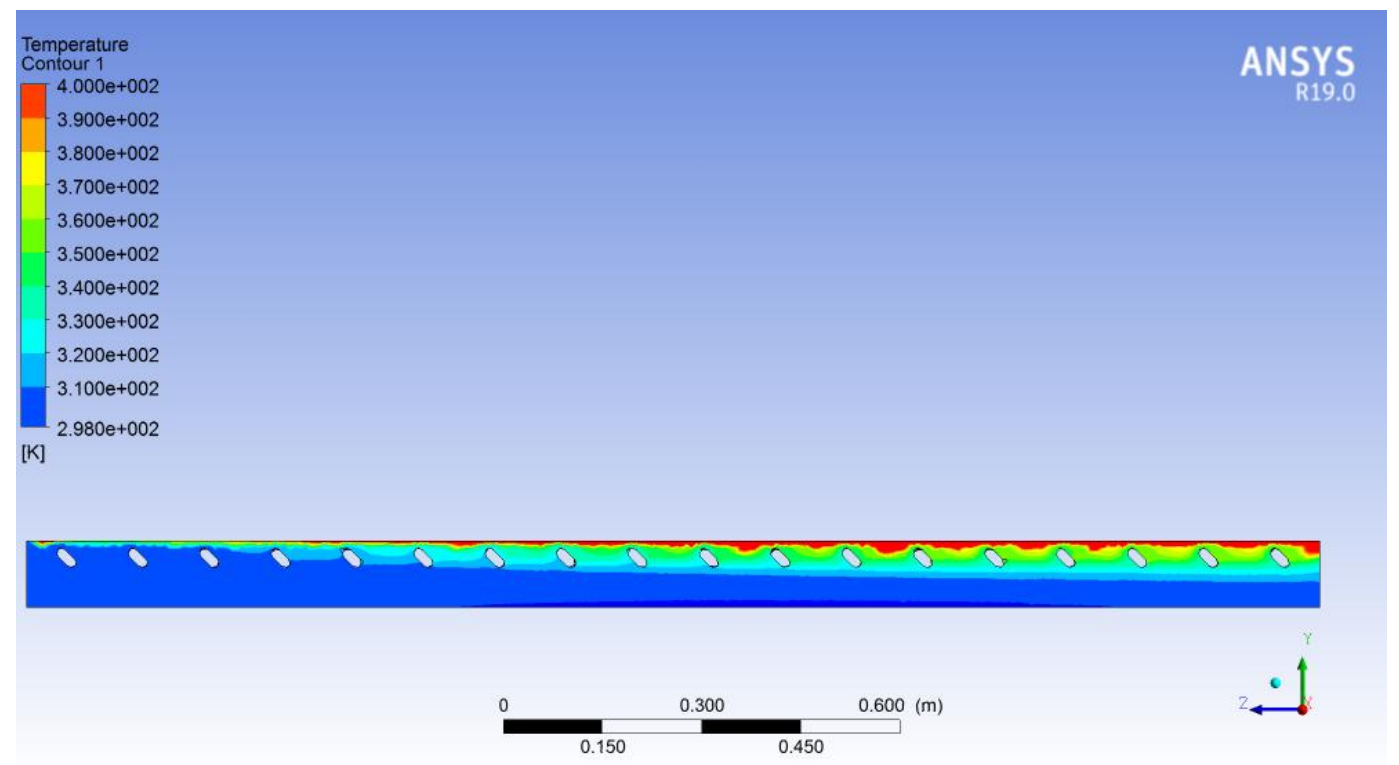

Fig.9. The optimum mass airflow rate determined by the numerical simulation program and who has outlet air temperature $328.76 \mathrm{k}$

\subsection{Angle tilted of air guides}

It is necessary to determine the optimal angle in which the air guides are directed to direct the largest amount of air to the base of the cell to increase the heat exchange. If the angle is too large, the air guides will act as a barrier to airflow and thus increase pressure drop.If the tilt of the air guides counterclockwise is too low , a small amount of air flows towards the base of the cell and a large amount of air flows under the air guides, preventing it from reaching the base of the cell, which reduces the heat exchange rate, which means that the air guides lead Reverse function when the tilt angle of the air guides is low, so it is necessary to determine the appropriate angle to tilt the air guides that increase the heat exchange rate and reduce the pressure drop

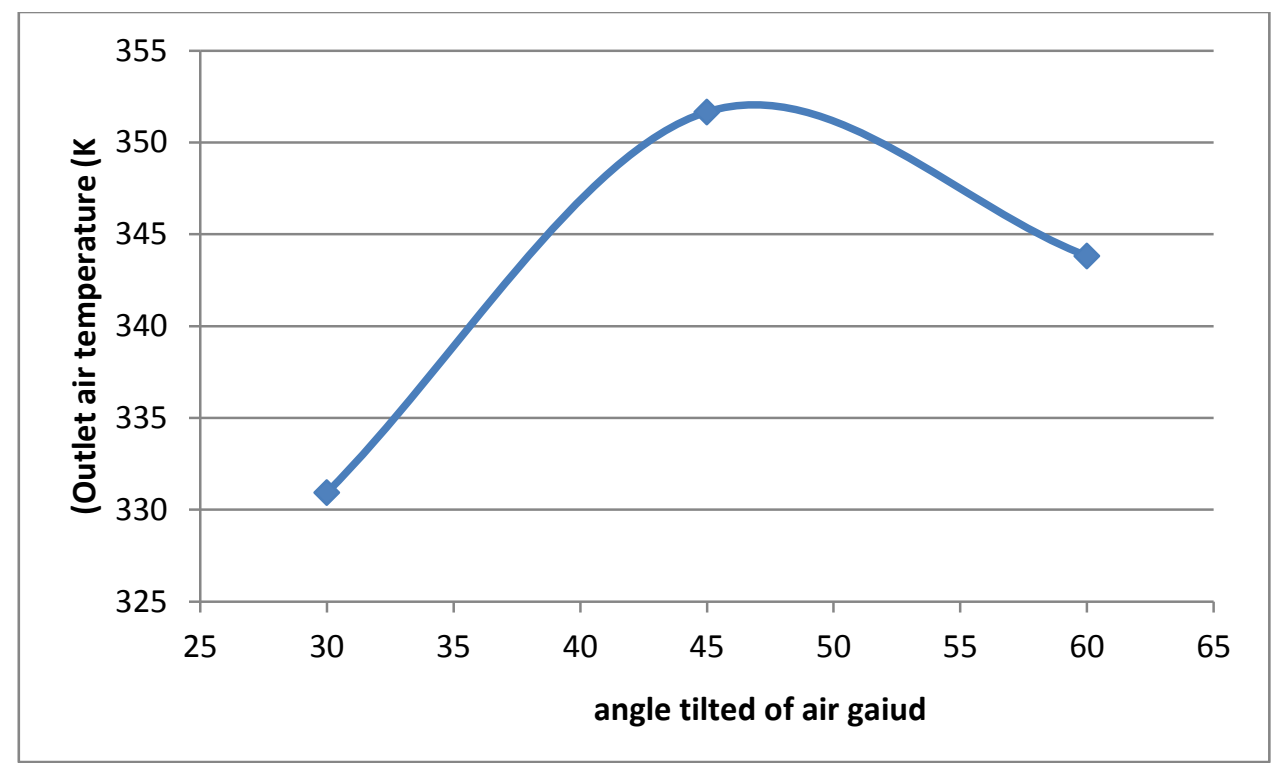

Fig. 10. Test the tilt angle of the air guides toward the base of the cell by CFD PRGRAM 


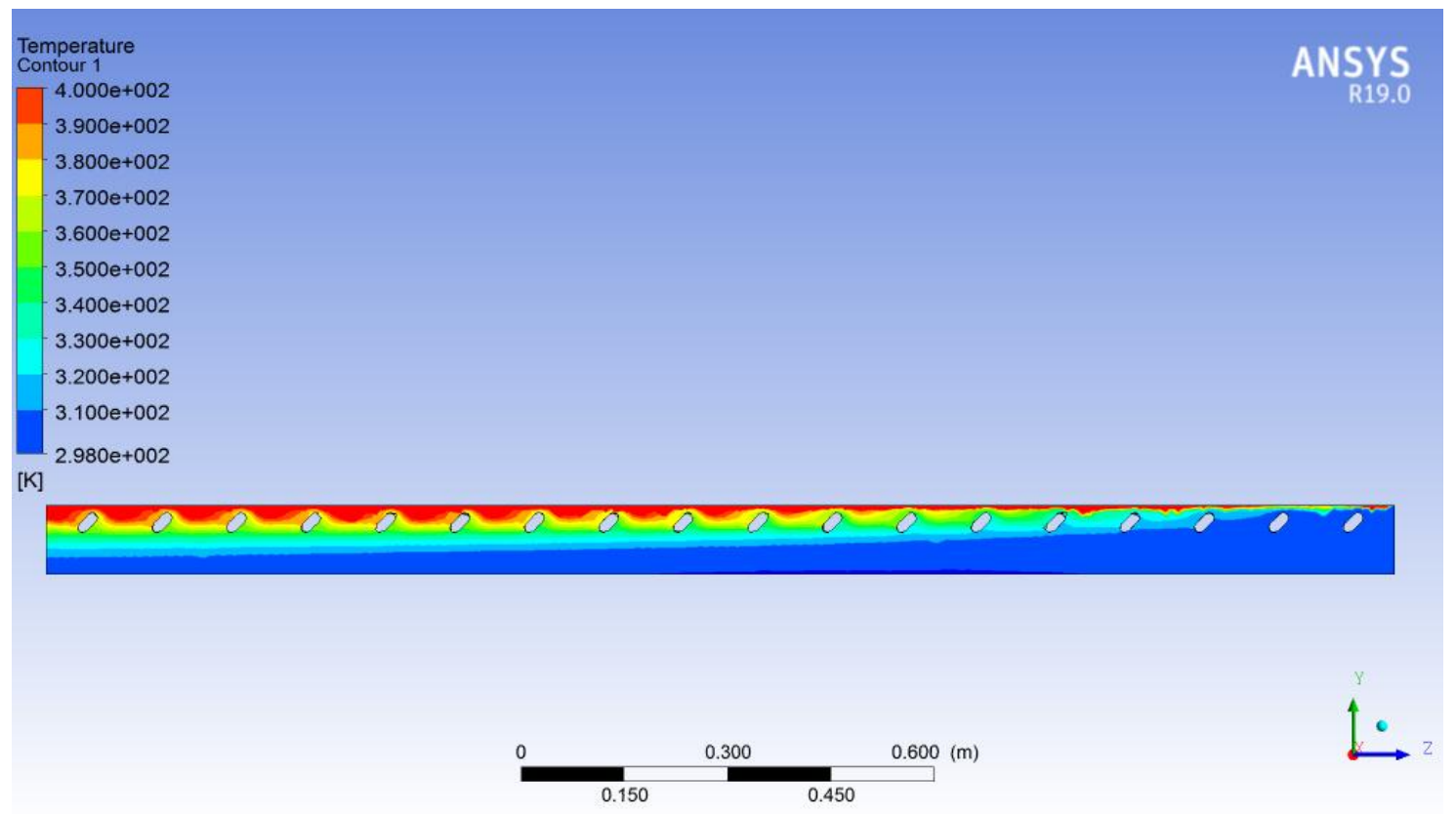

Fig. 11. the optimum tilt angle of air guides is determined by the numerical simulation program which has the temperature of the outgoing air $350.05 \mathrm{~K}$

\section{Conclusion}

In this manuscript, the best design of air-cooled PV cell is verified by the use of air guides that direct air towards the base of the PV cell and increase the heat exchange between the base of the cell and the flowing

air. The models were compared based on the highest air temperature from the exchange. In order to achieve the best design, the number of air guides was tested, the tilt angle of the air guides was tested, the location of the air guides inside the air duct was tested and the mass flow rate of the air was tested all in the same circumstances. It was concluded that the best number of air guides can be used is 18 evenly distributed inside the air duct with a tilt angle of 45 degrees and its location within the air duct 30 millimeters from the base of the photovoltaic cell at which the outside air temperature was 345.24 degrees Celsius. The best mass flow of air towards the base of the PV cell is $0.01 \mathrm{~kg} / \mathrm{s}$. This model and its outputs are tested in practice to verify the conformity of the results.

\section{References}

[1] A. Palumbo, "Design and Analysis of Cooling Methods for Solar Panels," Clim. Chang. 2013 - Phys. Sci. Basis, no. December 2013, pp. 1-30, 2013.

[2] M. H. K. Aboaltabooq et al., "Optimum operation conditions and behavior of organic rankine cycle system under variable heat input with control on refrigerant mass flow rate," UPB Sci. Bull. Ser. D Mech. Eng., vol. 77, no. 3, pp. 17-28, 2015.

[3] Z. Syafiqah, N. A. M. Amin, Y. M. Irwan, M. S. A. Majid, and N. A. Aziz, "Simulation study of air and water cooled photovoltaic panel using ANSYS," J. Phys. Conf. Ser., vol. 908, no. 1, 2017.

[4] M. Zohri, S. Hadisaputra, and A. Fudholi, "Exergy and energy analysis of photovoltaic thermal (Pvt)with and without fins collector," ARPN J. Eng. Appl. Sci., vol. 13, no. 3, pp. 803-808, 2018.

[5] J. A. D. Deceased and W. A. Beckman, Design of Photovoltaic Systems. 2013.

[6] M. F. Ariza Taba, M. Mwanza, N. S. Çetin, and K. Ülgen, "Assessment of the energy generation potential of photovoltaic systems in Caribbean region of Colombia," Period. Eng. Nat. Sci., vol. 5, no. 1, pp. 55-60, 2017.

[7] M. H. K. Aboaltabooq et al., "Effect of variable heat input on the heat transfer characteristics in an 
Organic Rankine Cycle system,” Renew. Energy Environ. Sustain., vol. 1, p. 13, 2016.

[8] J. Oh, "Building Applied and Back Insulated Photovoltaic Modules: Thermal Models," no. December, 2010.

[9] I. E. Maree and A. G. Ismaeel, "Experimental and Theoretical Calculation of Efficiency for Flat Plate Solar Collectors in Erbil City,” vol. 7, no. 2, pp. 786-793, 2019.

[10] O. V Ekechukwu and B. Norton, "Review of solar-energy drying systems III: low temperature airheating solar collectors for crop drying applications Ekechukwu, O. V. and Norton, B. Energy Conversion and Management, 1999, 40, (6), 657-667," Fuel Energy Abstr., vol. 40, no. 3, p. 216, 1999.

[11] T. Ghizlane, O. Hassan, B. Abdelkader, and B. Omar, "Single solar cell ideality factor determination using a fixed point method," Period. Eng. Nat. Sci., vol. 6, no. 2, pp. 331-337, 2018.

[12] A. S. Joshi, A. Tiwari, G. N. Tiwari, I. Dincer, and B. V Reddy, "Performance evaluation of a hybrid photovoltaic thermal (PV/T) (glass-to-glass) system," Int. J. Therm. Sci., vol. 48, no. 1, pp. 154-164, 2009.

[13] A. Mohsinalsayah, M. Hatf, K. Aboaltabooq, M. H. Majeed, and A. A. Al-najafy, "Journal of Mechanical Engineering Research and Developments ( JMERD ) MULTIPLE MODERN METHODS FOR IMPROVING PHOTOVOLTAIC CELL EFFICIENCY BY COOLING : A REVIEW,” vol. 42, no. 4, pp. 52-59, 2019.

[14] A. Kasaeian, Y. Khanjari, S. Golzari, O. Mahian, and S. Wongwises, "Effects of forced convection on the performance of a photovoltaic thermal system: An experimental study," Exp. Therm. Fluid Sci., vol. 85, pp. 13-21, 2017.

[15] A. S. Káiser and B. Zamora, "Improving the Electrical Parameters of a Photovoltaic Panel by Means of an Induced or Forced Air Stream," vol. 2013, 2013.

[16] B. R. Munson, D. F. Young, T. H. Okiishi, and W. W. Huebsch, "Fundamentals of Fluid Mechanics 6th Munson, young, Okiishi, Huebsch.pdf."

[17] J. F. Jf, L. J. Marks, J. A. S. E. Stewart, M. L. Dorsy, W. Watson-wrighi, and J. S. F. Lawrsrrcs, "FluidMechanics-Streeter.pdf," 1992. 